\title{
Influence of feeding strategy and diet for reproductive rabbit does on intake, performances, and health of young and females before and after weaning 1
}

\author{
T. Read, ${ }^{*}$ S. Combes, $*$ T. Gidenne, ${ }^{*}$ N. Destombes, $\uparrow$ K. Bébin, $\ddagger$ E. Balmisse, $\S$ and L. Fortun-Lamothe ${ }^{* 2}$ \\ *GenPhySE, Université de Toulouse, INRA, INPT, INP-ENVT, Castanet Tolosan, France, 31326; \\ $\dagger$ Terrena, La Noëlle, BP 20199, Ancenis, France, 44155; $\ddagger$ Groupe CCPA, ZA du Bois de Teillay, \\ Quartier du Haut-Bois, Janzé, France, 35150; and §PECTOUL, INRA, Castanet-Tolosan, France, 31326
}

\begin{abstract}
This study aimed to determine the influences of feeding strategy and diet for reproductive females on feed intake, BW, reproductive performances, and milk composition and their effects on kit performances from birth (d 0$)$ to $70 \mathrm{~d}$ of age (d 70). A total of 133 does followed for 3 reproductive cycles and their offspring, 2,322 kits from 236 litters, were divided into 3 experimental groups that differed only by the diet offered to the doe. Three experimental diets were used: a reproduction (Repro) diet (11.01 MJ $\mathrm{DE} / \mathrm{kg}, 24.0 \mathrm{~g}$ lipids $/ \mathrm{kg}, 161 \mathrm{~g} \mathrm{starch} / \mathrm{kg}$, and $343 \mathrm{~g} / \mathrm{kg}$ NDF), a lactation (Lact) diet (11.88 MJ DE/kg, $49.0 \mathrm{~g}$ lipids/kg, $161 \mathrm{~g} \mathrm{starch} / \mathrm{kg}$, and $302 \mathrm{~g} / \mathrm{kg} \mathrm{NDF}$ ), and a fattening (Fatt) diet (9.73 MJ DE/kg, $23.0 \mathrm{~g}$ lipids $/ \mathrm{kg}$, $70 \mathrm{~g} \mathrm{starch} / \mathrm{kg}$, and $415 \mathrm{~g} / \mathrm{kg}$ NDF). In group RR, does received feed Repro throughout the study (d 0 to 42 of each cycle). In group RF, does received diet Repro from d 0 to 25 and d 35 to 42 and diet Fatt from d 25 to 35 . In group LR, does received diet Lact from $\mathrm{d} 0$ to 25 and diet Repro from d 25 to 42 . Kits in all groups received diet $\mathrm{F}$ from $\mathrm{d} 18$ to 70 , where intake was restricted from d 35 to 63 . Doe BW was similar throughout the study $(4,495 \mathrm{~g} ; P>0.05)$. Doe feed intake differed only from weaning to the subsequent kindling $(+7.8 \%$ in group
\end{abstract}

RF; $P=0.042)$. Reproductive performances were similar, except for litter weight at birth $(+3.6 \%$ in group LR; $P=0.029$ ). From d 0 to 25 , a negative energy balance was observed in does yet most markedly in group LR (-8.61 MJ vs. -3.15 and -2.39 for groups $\mathrm{RF}$ and $\mathrm{RR}$, respectively; $P<0.01)$. Milk intake per kit was greater in group LR than in the other 2 groups at $17 \mathrm{~d}(+14.5 \%$; $P<0.001)$ and $23 \mathrm{~d}(+14.9 \% ; P<0.05)$. Kit BW was highest in group LR at 18 and $25 \mathrm{~d}(+10.1 \%$ and $+8.2 \%$, respectively; $P<0.01$ ), but no difference was observed at 35 or $70 \mathrm{~d}(P>0.05)$. Feed intake per kit from d 18 to 25 was greater in groups RR and RF than in group LR $(+26 \% ; P<0.001)$ and greater in group RF than in group LR from d 25 to $35(+8 \% ; P<0.05)$. Feed intake, when fed ad libitum (63 to $70 \mathrm{~d}$ ), was similar in all groups $(P=0.292)$. Kit mortality before weaning was similar in all groups $(8.1 \% ; P>0.05)$ but was lowest in group RF after weaning compared to groups RR and LR (1.7 vs. 4.8 and 5.8\%, respectively; $P<0.001$ ). Our results suggest that stimulating milk production through the incorporation of fat at the beginning of lactation offers few benefits for females and had a negative effect on early solid feed intake, which could explain animal health after weaning.

Key words: feed intake, health, milk intake, rabbit, weaning doi:10.2527/jas2016-0678

\section{INTRODUCTION}

\footnotetext{
${ }^{1}$ The authors gratefully acknowledge the technical help of Carole Bannelier, Corinne Pautot, Brigitte Gestes (INRA, UMR 1388 GenPhySE), Cécile Perrier, and Yolande Jaguelin (INRA, UMR 1348 PEGASE) and the assistance of the staff at the rabbit experimental unit (PECTOUL, Toulouse, France).

${ }^{2}$ Corresponding author: laurence.lamothe@toulouse.inra.fr Received May 27, 2016.

Accepted August 29, 2016.
}

The increase in rabbit doe productivity, notably prolificacy and reproductive rates, has drastically changed their nutritional demands in recent years. The competing demands of gestation and lactation have a negative effect on body condition, reproductive parameters, and milk yield (Savietto et al., 2016). While feed composition and feeding systems have evolved with time, there is only 1 feeder per cage for both does and 
suckling kits. However, their nutritional needs are antagonistic, as they require, respectively, a high level of energy to support lactation and a high level of fiber for digestive health (Gidenne and Fortun-Lamothe, 2002). In this context, the most popular feeding strategy in France is to distribute a diet rich in DE and protein a few days before kindling until $25 \mathrm{~d}$ postpartum (FortunLamothe et al., 2005) to meet the high nutritional needs of females during this period, followed by a diet rich in fiber until weaning to safeguard kits from digestive problems after weaning (Gidenne, 2003). While effective in terms of litter health, this strategy does not satisfy the requirements of concurrently gestating and lactating does (Xiccato and Trocino, 2010) and causes the does to lose body condition. The introduction of different feeding strategies that are adapted to the physiological state of each category of animal could thereby improve both doe and kit performances.

This study aimed to determine 1) the influences of separate feeding strategies and diets for reproductive does on their BW, feed intake, reproductive performance, and milk composition and 2) the influence of the doe feeding strategy on milk and solid feed intake, growth performance, and the health of rabbit kits from birth to $70 \mathrm{~d}$ of age. The experimental diets aimed to cover the nutritional needs of the does (De Blas and Mateos, 2010), increase milk production through the addition of lipids (Maertens et al., 2006), or optimize the digestive health of rabbit kits (Gidenne, 2015).

\section{MATERIALS AND METHODS}

\section{Animals, Diet, and Experimental Design}

This study was performed in strict accordance with the European Union (2010) recommendations on the protection of animals used for scientific purposes at the PECTOUL Experimental Unit (INRA, Toulouse, France). The protocol was approved by the ethics committee of the Ministère de l'Education Nationale, de l'Enseignement Supérieur et de la Recherche branch of the French government (permit number 2015100817517471).

Three experimental diets were used during the experiment (Table 1). The DE and protein content of the diets were determined through a digestibility trial performed on 54 growing rabbits (18 animals per diet reared in collective cages of 3 animals/cage) for $42 \mathrm{~d}$ using the European standardized method (Perez et al., 1995). The reproduction (Repro) diet was formulated to meet the nutrient needs of reproductive females and was rich in DE (11.01 MJ DE/kg), in digestible protein (DP; $128 \mathrm{~g} \mathrm{DP} / \mathrm{kg})$, and in starch $(161 \mathrm{~g} / \mathrm{kg})$ but poor in $\mathrm{ADF}$, $\mathrm{NDF}$, and ADL (198, 343, and $89 \mathrm{~g} / \mathrm{kg}$, respectively). The lactation (Lact) diet was also formulated to meet
Table 1. Ingredients and chemical composition of experimental diets

\begin{tabular}{|c|c|c|c|}
\hline Item & Fatt $^{1}$ & Repro $^{1}$ & Lact $^{1}$ \\
\hline \multicolumn{4}{|l|}{ Ingredients, $\mathrm{g} \cdot 100 \mathrm{~g}^{-1}$} \\
\hline Wheat & 0 & 5 & 15 \\
\hline Barley & 3 & 13 & 5 \\
\hline Wheat middling & 23 & 25 & 17 \\
\hline Rapeseed meal " 00 " & 3 & 9 & 15 \\
\hline Sunflower meal & 23 & 23 & 23 \\
\hline Molasses & 2 & 2 & 2 \\
\hline Fruit pulp & 11 & 6 & 8 \\
\hline Beet pulp & 26 & 10 & 9 \\
\hline Alfalfa & 3 & 2 & 2 \\
\hline Rapeseed oil & 0 & 0 & 2 \\
\hline Sunflower hull & 5 & 3 & 0 \\
\hline Minerals $^{2}$ & 1.4 & 1.7 & 1.6 \\
\hline $\mathrm{AA}^{3}$ & 0.2 & 0.1 & 0.2 \\
\hline Vitamin premix ${ }^{4}$ & 0.2 & 0.2 & 0.2 \\
\hline \multicolumn{4}{|c|}{ Chemical composition ${ }^{5}, \mathrm{~g} \cdot \mathrm{kg}^{-1}$} \\
\hline Crude fat & 23 & 24 & 49 \\
\hline $\operatorname{Starch}^{6}$ & 70 & 161 & 161 \\
\hline $\mathrm{ADF}$ & 247 & 198 & 169 \\
\hline $\mathrm{NDF}$ & 415 & 343 & 302 \\
\hline $\mathrm{ADL}$ & 123 & 89 & 63 \\
\hline Digestible fiber ${ }^{7}$ & 269 & 212 & 190 \\
\hline $\mathrm{DE}^{8}, \mathrm{MJ} \cdot \mathrm{kg}^{-1}$ & 9.73 & 11.01 & 11.88 \\
\hline Digestible proteins ${ }^{8}$ & 94 & 128 & 134 \\
\hline
\end{tabular}

${ }^{1}$ Diets: Fatt (fattening diet), diet formulated to meet the needs of growing rabbits; Repro (reproductive diet), diet formulated to meet the needs of reproductive females; Lact (lactation diet), diet formulated to meet the needs of reproductive females and to increase milk production.

${ }^{2}$ Calcium carbonate, dicalcium phosphate, salt, clay.

${ }^{3}$ Lysine $(0.1,0.18$, and 0.2 in feed $\mathrm{R}, \mathrm{L}$, and F, respectively); Threonine, 0.02 in feed $\mathrm{L}$.

${ }^{4}$ Vitamins: A, D3, B1, E; Oligo elements: Cu2+, Fe2+, Zn2+, Mn2+.

${ }^{5}$ Analyzed chemical composition, unless otherwise specified.

${ }^{6}$ Calculated according to the table of ingredients (Ponter et al., 2004).

${ }^{7}$ Calculated as the sum of (NDF - ADF) and water insoluble pectins according to the table of ingredients (Maertens et al., 2002).

${ }^{8}$ Measured on growing rabbits $(n=54)$ according to Perez et al. (1995).

the needs of reproductive females, but it was richer in energy (11.88 MJ DE/kg) than the R diet due to the addition of lipids ( $49 \mathrm{~g}$ crude fat $/ \mathrm{kg}$ ). The fattening (Fatt) diet was formulated to meet the nutrient needs of fattening rabbits and was therefore lower in DE (9.73 MJ DE/ $\mathrm{kg})$, starch $(70 \mathrm{~g} / \mathrm{kg})$, and protein content $(95 \mathrm{~g} \mathrm{DP} / \mathrm{kg})$ than the other 2 diets but had a greater ADF, NDF, and $\operatorname{ADL}$ content (247, 415, and $123 \mathrm{~g} / \mathrm{kg}$, respectively).

The fatty acid (FA) profiles of the experimental diets are shown in Table 2. Due to rapeseed meal and oil inclusion in the L diet, it contained more MUFA and less SFA and PUFA than the $\mathrm{R}$ and $\mathrm{F}$ diets. The $\mathrm{L}$ diet contained more C18:1 n-9c, C18:1 n-7, and C18:3 n-3 and less $\mathrm{C} 16: 0$ and $\mathrm{C} 18: 2 \mathrm{n}-6 \mathrm{c}$ than the other 2 diets. The $\mathrm{F}$ and $\mathrm{R}$ diets contained more $\mathrm{n}-6$ and less $\mathrm{n}-3 \mathrm{FA}$, 
Table 2. Fatty acid composition (percentage of total fatty acids on an as fed basis) of experimental diets

\begin{tabular}{|c|c|c|c|}
\hline & \multicolumn{3}{|c|}{ Diets $^{1}$} \\
\hline & Fatt & Repro & Lact \\
\hline Total lipids, $g \cdot 100 \mathrm{~g}^{-1}$ & 2.38 & 2.35 & 4.42 \\
\hline \multicolumn{4}{|c|}{ Fatty acid profile ( $\%$ total fatty acids) } \\
\hline $\mathrm{C} 6: 0$ & 0.05 & 0.00 & 0.00 \\
\hline $\mathrm{C} 8: 0$ & 0.05 & 0.05 & 0.01 \\
\hline C10:0 & 0.04 & 0.03 & 0.01 \\
\hline $\mathrm{C} 12: 0$ & 0.10 & 0.05 & 0.03 \\
\hline C14:0 & 0.22 & 0.18 & 0.10 \\
\hline $\mathrm{C} 15: 0$ & 0.17 & 0.14 & 0.08 \\
\hline C16:0 & 15.94 & 15.67 & 9.18 \\
\hline C18:0 & 2.77 & 2.22 & 2.00 \\
\hline $\mathrm{C} 20: 0$ & 0.47 & 0.45 & 0.52 \\
\hline $\mathrm{C} 22: 0$ & 0.68 & 0.57 & 0.38 \\
\hline $\mathrm{C} 24: 0$ & 0.84 & 0.51 & 0.22 \\
\hline Total SFA & 21.33 & 19.88 & 12.53 \\
\hline $\mathrm{C} 14: 1$ & 0.05 & 0.00 & 0.00 \\
\hline C16:1 n-9 & 0.10 & 0.09 & 0.06 \\
\hline C16:1 n-7 & 0.37 & 0.39 & 0.30 \\
\hline $\mathrm{C} 18: 1 \mathrm{n}-9 \mathrm{c}$ & 25.70 & 21.93 & 40.69 \\
\hline C18:1 n-7 & 1.45 & 2.61 & 3.24 \\
\hline C20:1 n-9 & 0.56 & 0.54 & 0.94 \\
\hline C22:1 n-11 & 0.05 & 0.10 & 0.28 \\
\hline $\mathrm{C} 24: 1$ & 0.08 & 0.17 & 0.09 \\
\hline Total MUFA & 28.36 & 25.82 & 45.60 \\
\hline $\mathrm{C} 18: 2 \mathrm{n}-6 \mathrm{c}$ & 45.18 & 48.29 & 31.14 \\
\hline C18:3 n-3 & 3.94 & 4.79 & 10.4 \\
\hline C20:2 & 0.13 & 0.19 & 0.06 \\
\hline C20:4 n-6 & 0 & 0.05 & 0.03 \\
\hline C20:3 n-3 & 0.20 & 0.22 & 0.03 \\
\hline $\mathrm{C} 20: 4$ n-3 & 0.21 & 0.14 & 0.04 \\
\hline C20:5 n-3 & 0.47 & 0.38 & 0.11 \\
\hline C22:4 n-6 & 0.18 & 0.13 & 0.07 \\
\hline C22:6 n-3 & 0 & 0.10 & 0 \\
\hline PUFA & 50.31 & 54.30 & 41.88 \\
\hline$n-6$ & 45.36 & 48.48 & 31.24 \\
\hline$n-3$ & 4.82 & 5.64 & 10.58 \\
\hline$n-6 / n-3$ & 9.42 & 8.60 & 2.95 \\
\hline
\end{tabular}

${ }^{1}$ Diets: Fatt (fattening diet), diet formulated to meet the needs of growing rabbits; Repro (reproductive diet), diet formulated to meet the needs of reproductive females; Lact (lactation diet), diet formulated to meet the needs of reproductive females and to increase milk production. Analyzed according to Folch et al. (1957).

which explains the greater $n-6 / n-3$ ratio in these 2 diets compared to the $\mathrm{L}$ diet.

A total of 2,322 kits, from 236 litters, issued from 133 females (INRA $1,777 \times 2,266$ ) during 3 successive reproductive cycles were used in this study. The experiment started the day of kindling ( $\mathrm{d} 0$ ) with 60 primiparous and 60 secondiparous does. A total of 13 nulliparous females were introduced for the second reproductive cycle to replace females lost due to mortality or culling. Animals were culled due to health reasons but not in function of their reproductive performance. Does, and their litter when appropriate, were housed individually in wire cages ( 61 by 68 by $35 \mathrm{~cm}$ [width by length by height]) containing a nest box for kits (39 by 27 by $35 \mathrm{~cm}$ [width by length by height]) and maintained in a ventilated breeding unit with a 16-h light schedule ( 0600 to 2200 h). Cages were equipped to feed the kits independently from their mother (Fortun-Lamothe et al., 2000). Kits had access to the mothers' area to suckle. The separated feeding system was put in place at $18 \mathrm{~d}$ of age. After weaning ( $35 \mathrm{~d})$, the litters were split into cages of 5 kits/cage from the same litter $(n=119,126$, and 122 cages for the RF, RR and LR groups, respectively).

Animals were distributed at parturition into 1 of 3 experimental groups, taking into account the does BW $(4,170 \pm 30 \mathrm{~g})$ and parity $(1.4 \pm 0.1)$ at parturition as well as the litter size (12 \pm 1 kits) and weight (731 \pm 20 g) to obtain homogenous groups. The litters were equalized by cross-fostering or culling intra group at 9 and 10 kits, for primiparous and multiparous does, at $3 \mathrm{~d}$ after birth $(0 \mathrm{~d})$. Artificial insemination of does took place 11 $\mathrm{d}$ after giving birth; therefore, the reproductive cycle lasted $42 \mathrm{~d}$ (interval between 2 kindlings). Females were prepared for AI by an injection of 40 IU of PMSG 48 $\mathrm{h}$ before insemination was performed and $0.2 \mathrm{~mL}$ of $\mathrm{GnRH}$ following insemination. Experimental groups differed only by the feeding strategy used for females. All females were fed ad libitum throughout the study. In the RF group, the does received diet Repro from $\mathrm{d} 0$ to 25 and from weaning (d 35) to 42 and diet Fatt from d 25 to 35 . This feeding strategy mimics the current practice in French rabbit commercial farms. In the RR group, the does received feed Repro throughout the study ( $d$ 0 to 42 of each cycle). This feeding strategy aimed to be straightforward and was based on a single diet for females while optimizing their performances and preserving their BCS due to the starch-based high dietary energy level in the diet offered all along the reproductive life. This strategy also should limit the adverse effects of dietary changes on intake and health. In the LR group, the does received diet Lact from d 0 to 25 and diet Repro from $\mathrm{d} 25$ to 42 . This feeding strategy aimed to stimulate milk production at the beginning of lactation to increase the growth of suckling rabbits, due to the addition of fat in the diet, and to help the females to restore their body reserves before the next kindling, due to the starchbased high-energy diet. The possible reduction of milk production at the end of lactation due to the introduction of a diet less rich in fat should stimulate the kits' feed intake and, in turn, cecal microbiota maturation. In the 3 groups, does that were not pregnant received feed $\mathrm{R}$ ad libitum until the next kindling to avoid excessive fattening (LR group) or body reserve depletion (RF group). Kits in the 3 groups were fed feed $F$ from 18 to $70 \mathrm{~d}$. The feed intake of young rabbits was restricted to $70 \%$ of ad 
libitum cages (measured in 26 cages with 129 rabbits) from 35 to $63 \mathrm{~d}$ and distributed ad libitum outside of this period. During the restriction period, young rabbits received $70 \mathrm{~g}$ /rabbit daily from d 35 to $42,90 \mathrm{~g} /$ rabbit daily from d 42 to $49,110 \mathrm{~g} /$ rabbit daily from d 49 to 56 , and $130 \mathrm{~g} /$ rabbit daily from d 56 to 63 . During this period of restricted feeding, the feed was distributed daily. When feed was distributed ad libitum, the feeder was refilled at each assessment of feed intake and between measurements when necessary. No antibiotics, in either feed or water, were used throughout this study.

\section{Measurements}

The fertility rate was estimated as the percentage of the number of kindlings per number of AI. The results of the $3 \mathrm{AI}$ performed during the experiment were considered, as they are influenced by the experimental feeding strategies; however, the AI that resulted in the first experimental kindling was excluded, as it occurred before the start of the experiment. Rabbit does were weighed and feed intake was measured at each kindling, at AI (d 11), at d 25, and at weaning (d 35). A milk sample ( $5 \mathrm{~mL} /$ doe) was collected using a milking machine (Lebas, 1970) on d 16 after kindling from 15 does per treatment during the first and third experimental cycle of reproduction. At the time of milk sample collection, an injection of oxytocin (3 IU) was injected intravenously in the marginal vein of the ear. The mortality of female rabbits was recorded daily.

Total litter size was recorded at birth, including the number of dead born kits. Litter size at weaning was also recorded. Litter weight was recorded at kindling (d 0), during the equalization of litters (d 3), and then weekly until $\mathrm{d} 18$. The individual BW of the rabbits were recorded weekly from 18 to $70 \mathrm{~d}$ of age. Milk intake was measured once per week from $\mathrm{d} 3$ until weaning by weighing the litter immediately before and after nursing (Lebas, 1968). Access to the mother was inhibited $24 \mathrm{~h}$ before milk intake measurements. Feed intake per litter or cage, before or after weaning respectively, was measured on d 25 and 35 and then weekly until $\mathrm{d} 70$. The health status of the rabbits was monitored at each weighing. Mortality of kits was recorded daily from d 3 to 70 .

\section{Chemical Analysis}

Chemical analyses were performed on diets according to ISO methods and the recommendations of the European Group on Rabbit Nutrition (EGRAN, 2001): DM (24 h at $103^{\circ} \mathrm{C}$; method 6496.1999), OM, $\mathrm{CP}(\mathrm{N} \times$ 6.25; Dumas method; method 16634.2004), and crude energy (C5000; IKA, Staufen, Germany). Measurements of fibrous fractions (NDF, ADF, and
ADL) in the diets were performed according to the sequential method of Van Soest et al. (1991) with an amylolytic pretreatment (AFNOR, 1997; method 16472.2007 and method 13906.2008). Nitrogen levels were determined in the diets according to the Dumas combustion method using the Elementar autoanalyzer (model Vario El cube; Elementar, Hanau, Germany) and converted to $\mathrm{CP}(\mathrm{N} \times 6.25)$.

The extraction of lipids from fresh milk was performed according to the Folch method (Folch et al., 1957). After filtration and evaporation, lipid extracts were methylated according to the Morrison method (Morrison and Smith, 1964) in the presence of boron fluoride- methanol. Fatty acids were identified by gas phase chromatography (model 7890 with a flame ionization detector; Agilent, Santa Clara, CA). The gas vector used was hydrogen. The capillary column was a DB 225 (30 $\mathrm{mm}$ in length by $0.25 \mathrm{~mm}$ in diameter with a film thickness of $0.25 \mathrm{~mm}$ ) made of $50 \%$ cyanopropylphenyl-dimethylpolysiloxane. The duration of the run was $28 \mathrm{~min}$, with a starting temperature of $150^{\circ} \mathrm{C}$, which increased by $4^{\circ} \mathrm{C}$ per minute with a maximum temperature of $220^{\circ} \mathrm{C}$. Maximum temperature was maintained for $10.5 \mathrm{~min}$. The temperature of the flame ionization detector was $280^{\circ} \mathrm{C}$. The standards used for the identification of FA were PUFA 1, PUFA 2, PUFA 3 (Sigma-Aldrich, Saint-Quentin Fallavier, France), Fatty Acid Methyl Ester (FAME) 1, FAME 2, FAME 6, FAME 7, FAME 14, FAME 15, American Oil Chemists' Society 6 (Restek, Bellefonte, PA), K 103, and K 107 (Alltech, Deerfield, IL). The internal marker for the quantification of FA was $\mathrm{C} 17$.

\section{Calculations and Statistical Analysis}

Milk production of the does between 3 and $18 \mathrm{~d}$ of lactation was calculated according to Fortun-Lamothe and Sabater (2003). The energy balance of lactating females between initial kindling and 25d and between weaning and the following kindling were estimated according to Parigi-Bini and Xiccato (1998). The energy balance was calculated as the sum of the intake minus requirements, where the requirements for maintenance, lactation, and gestation were taken into consideration. The theoretical values for the energy content of milk and rabbit kits were used $(8.4 \mathrm{MJ} / \mathrm{kg}$ for milk and $5.32 \mathrm{MJ} / \mathrm{kg}$ for the litter, respectively; Parigi-Bini and Xiccato, 1998; Fortun-Lamothe et al., 1999).

All statistical analyses were performed using $\mathrm{R}$ version 3.0.3 (R Foundation for Statistical Computing, Vienna, Austria). Female or litter, depending on measurement, was the experimental unit. Feed intake, BW, and reproductive performances of females and growth, feed, and milk intake of rabbits were evaluated using 
Table 3. Effect of feeding strategy on live weight and feed intake of rabbit does

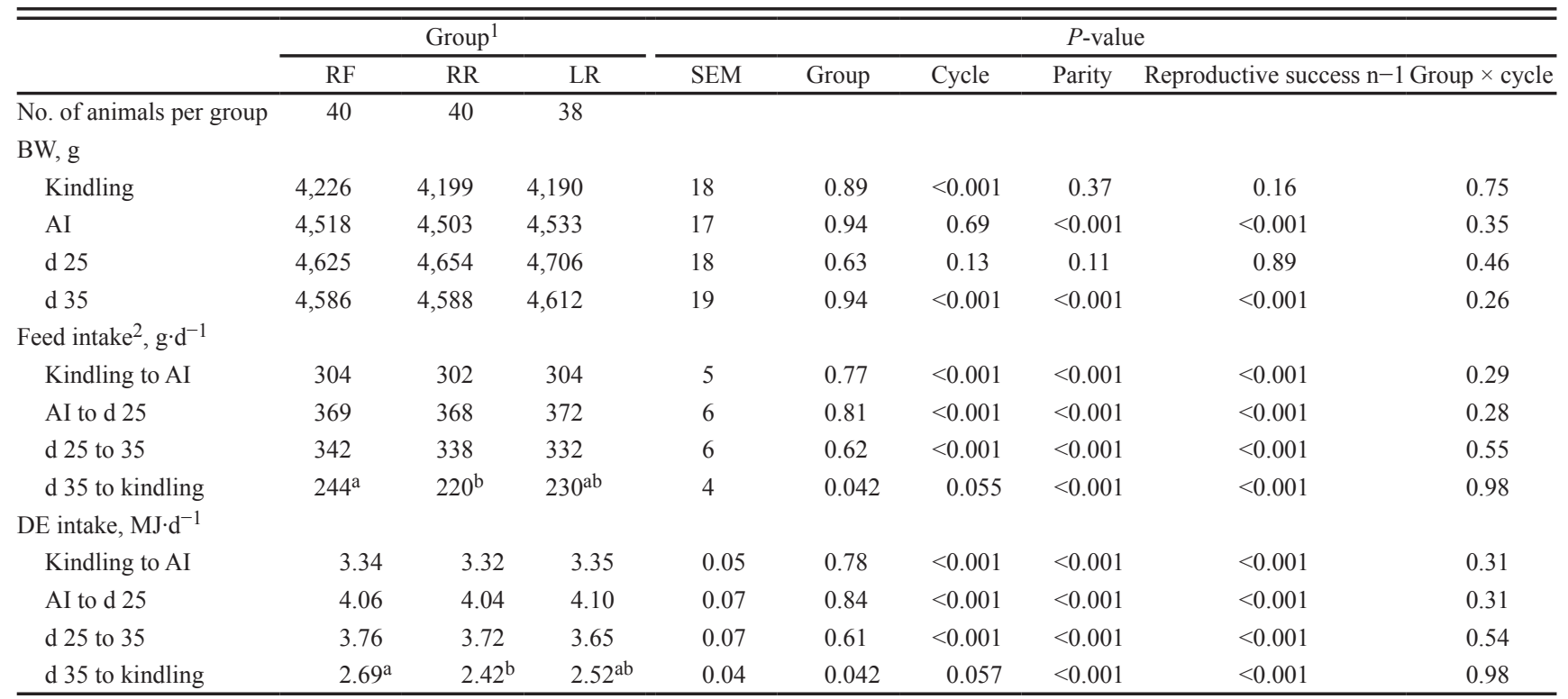

a,b Means within a row with different superscripts differ $(P<0.05)$.

${ }^{1}$ Group: reproduction-fattening $(\mathrm{RF})=$ reproduction (Repro) diet from 0 to $25 \mathrm{~d}$ and 35 to $42 \mathrm{~d}$, followed by the fattening (Fatt) diet from 25 to $35 \mathrm{~d}$; reproduction-reproduction $(\mathrm{RR})=\operatorname{diet}$ Repro from 0 to $42 \mathrm{~d}$; lactation-reproduction (LR) = lactation (Lact) diet from 0 to $25 \mathrm{~d}$, followed by diet Repro from 25 to $42 \mathrm{~d}$. Diet Repro (11.01 MJ DE $/ \mathrm{kg}, 24.0 \mathrm{~g}$ lipids $/ \mathrm{kg}, 161 \mathrm{~g}$ starch $/ \mathrm{kg}$, and $343 \mathrm{~g} / \mathrm{kg} \mathrm{NDF}$ ) was formulated to meet the nutrient needs of reproductive females. Diet Fatt (9.73 MJ DE $/ \mathrm{kg}, 23.0 \mathrm{~g}$ lipids $/ \mathrm{kg}, 70 \mathrm{~g}$ starch $/ \mathrm{kg}$, and $415 \mathrm{~g} / \mathrm{kg} \mathrm{NDF}$ ) was formulated to meet the nutrient needs of fattening rabbits. Diet Lact (11.88 MJ DE $/ \mathrm{kg}$, $49.0 \mathrm{~g}$ lipids $/ \mathrm{kg}, 161 \mathrm{~g}$ starch $/ \mathrm{kg}$, and $302 \mathrm{~g} / \mathrm{kg} \mathrm{NDF}$ ) was also formulated to meet the needs of reproductive females and to increase milk production.

${ }^{2}$ The feed intake presented is strictly that of the doe, as rabbit kits were inhibited from eating out of the doe feeder.

a linear mixed effects model, considering the effect of the experimental group (3 levels: RR, LR, and RF), the experimental reproductive cycle (3 levels: cycle 1 [C1], cycle $2[\mathbf{C 2}]$, and cycle $3[\mathbf{C 3}])$, the parity (5 levels: parity 1, 2, 3, 4, and 5), and the reproductive success for the previous cycle ( 2 levels: 0 or 1 ), as well as the interaction group $\times$ cycle as fixed effects and the doe as a random effect. Fertility was considered to be a Bernoulli variable. The energy balance was analyzed using a linear mixed model, where the experimental group, cycle, parity, reproductive success for the following cycle, and interaction group $x$ cycle were considered as fixed effects. The milk composition was analyzed using a linear mixed model, where the experimental group, the reproductive cycle, the parity, and the reproductive success for the previous cycle were fixed effects. The percentage of mortality was compared by a $\chi^{2}$ test.

The reproductive cycle, the parity of the doe, and the reproductive success of the previous cycle had a strong impact on several parameters as reported in Tables 3, 4, and 5. Such effects have been previously described in the literature (Poujardieu and TheauClément, 1995) and are not discussed here, especially as the interaction between group and cycle was not significant most of the time. When results were $(P<$ $0.05)$ or tended to be $(P<0.10)$ significant, it was mentioned in the Results section.

\section{RESULTS}

Total doe mortality throughout the study for the 3 groups was on average $24.6 \pm 3.9 \%$, and did not differ between the groups $(n=10,9$, and 10 does for the groups $\mathrm{RF}, \mathrm{RR}$, and LR, respectively; $P=0.85$; data not shown).

\section{Female Performance}

Doe BW was found to fluctuate according to the stage of the reproductive cycle (Table 3 ). Directly after kindling, doe BW was 4,205 $\pm 18 \mathrm{~g}$ on average for the 3 groups, and no difference was observed $(P=0.89)$. The BW was found to increase until $25 \mathrm{~d}$ after kindling $(4,661 \pm 18 \mathrm{~g} ; P=0.63)$ and then decrease at the time of weaning $(4,595 \pm 19 \mathrm{~g} ; P=0.94)$. From kindling to $25 \mathrm{~d}$ of lactation, the females who received the fat-enriched diet gained more weight than the females in the other 2 groups $(516 \pm 28 \mathrm{~g}$ vs. $427 \pm 30 \mathrm{~g} ; P=0.037$; data not shown). Feed intake of does was similar between the groups for the periods of kindling to AI, AI to d 25, and d 25 to 35 (Table 3). During the period between weaning and the subsequent kindling, does in the RF group had a greater intake than the does in the RR group, with the LR group as the intermediary $(P=0.042$; Table 3$)$.

The fertility rate observed during the study was on average $63.3 \pm 2.7 \%$ and did not differ between the groups $(P=0.48)$. The total number of kits born per litter 
Table 4. Effect of feeding strategy on reproductive performances of rabbit does

\begin{tabular}{|c|c|c|c|c|c|c|c|c|c|}
\hline & \multicolumn{3}{|c|}{ Group $^{1}$} & \multirow[b]{2}{*}{ SEM } & \multicolumn{5}{|c|}{$P$-value } \\
\hline & RF & $\mathrm{RR}$ & LR & & Group & Cycle & Parity & Reproductive suc & roup $\times$ cycle \\
\hline No. of litters ${ }^{2}$ & 47 & 48 & 52 & & & & & & \\
\hline Total born, $n$ & 14.1 & 13.3 & 14.4 & 0.3 & 0.29 & 0.057 & $<0.001$ & 0.007 & 0.95 \\
\hline Dead born, $n$ & 0.9 & 0.8 & 0.3 & 0.1 & 0.083 & 0.038 & 0.43 & 0.28 & 0.26 \\
\hline Litter weight at birth, $g$ & $777^{\mathrm{ab}}$ & $711^{\mathrm{b}}$ & $803^{\mathrm{a}}$ & 14 & 0.029 & 0.002 & 0.002 & 0.14 & 0.60 \\
\hline Kit weight at birth, $g$ & 59.8 & 59.7 & 59.5 & 0.8 & 0.99 & 0.090 & 0.004 & 0.002 & 0.71 \\
\hline Litter size at weaning, $n$ & 8.2 & 8.5 & 8.5 & 0.3 & 0.83 & 0.953 & 0.78 & 0.65 & 0.37 \\
\hline
\end{tabular}

a,b Means within a row with different superscripts $\operatorname{differ}(P<0.05)$.

${ }^{1}$ Group: reproduction-fattening $(\mathrm{RF})=$ reproduction (Repro) diet from 0 to $25 \mathrm{~d}$ and 35 to $42 \mathrm{~d}$, followed by the fattening (Fatt) diet from 25 to $35 \mathrm{~d}$; reproduction-reproduction $\mathrm{RR}=$ reproduction (Repro) diet from 0 to $42 \mathrm{~d}$; lactation-reproduction (LR) = lactation (Lact) diet from 0 to $25 \mathrm{~d}$, followed by diet Repro from 25 to $42 \mathrm{~d}$. Diet R (10.01 MJ DE $/ \mathrm{kg}, 24.0 \mathrm{~g}$ lipids $/ \mathrm{kg}, 161 \mathrm{~g} \mathrm{starch} / \mathrm{kg}$, and $343 \mathrm{~g} / \mathrm{kg} \mathrm{NDF}$ ) was formulated to meet the nutrient needs of reproductive females. Diet Fatt (9.70 MJ DE $/ \mathrm{kg}, 23.0 \mathrm{~g}$ lipids $/ \mathrm{kg}, 70 \mathrm{~g}$ starch $/ \mathrm{kg}$, and $415 \mathrm{~g} / \mathrm{kg} \mathrm{NDF}$ ) was formulated to meet the nutrient needs of fattening rabbits. Diet L (11.88 MJ DE/ $\mathrm{kg}$, $49.0 \mathrm{~g}$ lipids $/ \mathrm{kg}, 161 \mathrm{~g} \mathrm{starch} / \mathrm{kg}$, and $302 \mathrm{~g} / \mathrm{kg} \mathrm{NDF}$ ) was also formulated to meet the needs of reproductive females and to increase milk production.

${ }^{2}$ Only the reproductive performances from cycles 2 and 3 were taken into consideration, as the feeding strategy was put in place after the first kindling; therefore, the reproductive performance of the first cycle was not affected by feeding strategy.

was similar between the groups $(P=0.29$; Table 4$)$, yet there was a tendency for the does in group LR to have fewer dead born kits $(P=0.083)$. Thus, litter weight in the LR group was $+12.9 \%$ and $+3.2 \%$ heavier compared to groups RR and RF, respectively $(P=0.029)$, although kit BW at birth was similar between groups (59 $\pm 1 \mathrm{~g} ; P=0.99)$. No effect of feeding strategy was observed for litter size at weaning $(P=0.83)$.

\section{Milk Production and Composition}

Milk production from 3 to $18 \mathrm{~d}$ was greater in the LR group than in the other 2 groups $(3,911 \pm 86 \mathrm{~g}$ vs. $3,442 \pm 83 \mathrm{~g}$ and 3,388 $\pm 80 \mathrm{~g}$ for the groups $\mathrm{RR}$ and $\mathrm{RF}$, respectively; $P<0.001)$. Milk composition was strongly influenced by the feeding strategy (Table 5). The feeding strategy did not influence the total percentage of lipids found in the milk $(9.5 \pm 0.3 \%$ on average; $P=0.113)$, but the percentage of 24 of the 28 FA quantified in the diets were found to differ between groups. The 4 FA that did not differ between groups included 2 SFA (C6:0 and C18:0) and 2 PUFA (C18:2 n-6t and C20:2). A total of 6 FA were observed in the milk that were not present in the diets (C18:1 n-9t, C22:1 n-9, C18:2 n-6t, C18:3 n-6, C20:3 n-6, and C22:5 n-3). The milk produced by does in the LR group had a greater percentage of MUFA and PUFA than the other 2 groups $(+8.1$ points and +2.9 points MUFA and PUFA, respectively; $P<0.001$ ), while the percentage of SFA was lower $(-11.3$ points and -10.7 points compared to groups RR and RF, respectively; $P<$ $0.001)$. The ratio $n-6 / n-3$ was lower in the LR group by 6.9 points on average than the other groups $(P<0.001)$.

\section{Energy Balance}

The energy balance of lactating rabbit does during the first $25 \mathrm{~d}$ of the reproductive cycle was negative in all groups but was less pronounced in the RF and RR groups compared to the LR group $(-2.08 \pm 1.16 \mathrm{MJ}$ and $-2.01 \pm 1.05 \mathrm{MJ}$ vs. $-4.94 \pm 1.25 \mathrm{MJ}$; Table $6 ; P=$ 0.023 ). During the period from 35 to $42 \mathrm{~d}$, the energy balance of does in all groups was positive, although higher in the RF group than the RR and LR groups $(+7.14 \pm 0.82 \mathrm{MJ}$ vs. $+3.70 \pm 0.68 \mathrm{MJ}$ and $+3.63 \pm 0.76$ MJ; $P=0.003)$. Energy intake during the reproductive cycles was also found to vary according to the group from d 25 to 35 and from d 35 to $42(P<0.05)$. From d 25 to 35, energy intake was lowest in the RF group $(-10.8$ and $-4.1 \%$ compared to groups RR and LR, respectively; $P=0.003)$. From 35 to $42 \mathrm{~d}$, the energy intake of group RF was higher than the RR group $(+9.9 \%$; $P=0.006$ ), with group LR as the intermediary. The BW of lactating does did not differ between groups at kindling, AI, or at weaning, while at $25 \mathrm{~d}$ the LR group was heavier than the other 2 groups $(P=0.011)$.

\section{Milk and Feed Intake and Growth Performance of Young Before and After Weaning}

The treatment $\times$ day interaction for the milk intake of kits was not significant $(P>0.10)$. The milk intake of kits on $\mathrm{d} 3$ and 10 was on average $11.8 \pm 0.3$ and $24.2 \pm 0.5 \mathrm{~g} / \mathrm{kit}$, respectively, and was similar between the 3 groups (Fig. 1; $P>0.05$ ). However, at $\mathrm{d} 17$ and 23 , milk intake was highest in the LR group, ranging from 14 to $21 \%$ greater than the other 2 groups (Fig. 1; $P<0.05)$. Toward the end of lactation, d 29, average milk intake per kit was $13.8 \pm 0.6 \mathrm{~g}$ and did not differ between groups $(P=0.85)$. The feed intake of kits at the onset of solid feed intake (d 18 to 25) was lowest in the LR group compared to groups RR and RF $(7 \pm 0$ vs. $9 \pm 1$ and $10 \pm 1 \mathrm{~g} / \mathrm{d}$, respectively; Table 7; $P<0.001)$. From d 25 to 35, the feed intake of kits in group LR was $8 \%$ lower than that in the RF group, 
Table 5. Effect of feeding strategy on the milk composition of rabbit does at $16 \mathrm{~d}$ of lactation $(n=30,31$, and 31 for the reproduction-fattening [RF], reproduction-reproduction [RR], and lactation-reproduction [LR] groups, respectively) during the first and third reproductive cycle at $16 \mathrm{~d}$ of lactation

\begin{tabular}{|c|c|c|c|c|c|c|c|}
\hline & \multicolumn{3}{|c|}{ Group $^{1}$} & \multirow[b]{2}{*}{ SEM } & \multicolumn{3}{|c|}{$P$-value } \\
\hline & $\mathrm{RF}$ & $\mathrm{RR}$ & LR & & Group & Cycle & Reproductive success $n-1$ \\
\hline Total lipids, g/100 g & 8.8 & 9.9 & 9.8 & 0.3 & 0.113 & $<0.001$ & 0.525 \\
\hline \multicolumn{8}{|c|}{ Fatty acid profile ( $\%$ total fatty acids) } \\
\hline C6:0 & 0.33 & 0.35 & 0.31 & 0.01 & 0.060 & 0.408 & 0.152 \\
\hline C8:0 & $26.11^{\mathrm{a}}$ & $27.10^{\mathrm{a}}$ & $22.11^{b}$ & 0.34 & $<0.001$ & 0.892 & $<0.001$ \\
\hline C10:0 & $22.27^{\mathrm{a}}$ & $22.11^{\mathrm{a}}$ & $18.65^{\mathrm{b}}$ & 0.27 & $<0.001$ & 0.127 & $<0.001$ \\
\hline C12:0 & $2.81^{\mathrm{a}}$ & $2.71^{\mathrm{a}}$ & $2.29^{\mathrm{b}}$ & 0.05 & $<0.001$ & 0.069 & 0.018 \\
\hline C14:0 & $1.35^{\mathrm{a}}$ & $1.32^{\mathrm{ab}}$ & $1.00^{\mathrm{b}}$ & 0.02 & $<0.001$ & $<0.001$ & 0.002 \\
\hline $\mathrm{C} 15: 0$ & $0.35^{\mathrm{a}}$ & $0.34^{\mathrm{a}}$ & $0.30^{\mathrm{b}}$ & 0.00 & $<0.001$ & 0.004 & $<0.001$ \\
\hline C16:0 & $12.39^{\mathrm{a}}$ & $12.25^{\mathrm{a}}$ & $10.22^{b}$ & 0.16 & $<0.001$ & 0.003 & $<0.001$ \\
\hline C18:0 & 2.77 & 2.78 & 2.69 & 0.04 & 0.652 & 0.017 & $<0.001$ \\
\hline C20:0 & $0.09^{\mathrm{b}}$ & $0.09^{\mathrm{b}}$ & $0.13^{\mathrm{a}}$ & 0.00 & $<0.001$ & 0.293 & 0.678 \\
\hline C22:0 & $0.02^{\mathrm{ab}}$ & $0.02^{\mathrm{b}}$ & $0.03^{\mathrm{a}}$ & 0.00 & 0.040 & 0.1577 & 0.415 \\
\hline Total SFA & $68.50^{\mathrm{a}}$ & $69.06^{\mathrm{a}}$ & $57.72^{b}$ & 0.63 & $<0.001$ & 0.002 & $<0.001$ \\
\hline C16:1 n-9 & $0.25^{\mathrm{b}}$ & $0.25^{\mathrm{b}}$ & $0.29^{\mathrm{a}}$ & 0.00 & $<0.001$ & $<0.001$ & $<0.001$ \\
\hline C16:1 n-7 & $1.20^{\mathrm{a}}$ & $1.01^{\mathrm{ab}}$ & $0.84^{\mathrm{b}}$ & 0.06 & 0.021 & 0.053 & $<0.001$ \\
\hline $\mathrm{C} 18: 1 \mathrm{n}-9 \mathrm{t}^{2}$ & $0.02^{\mathrm{a}}$ & $0.02^{\mathrm{a}}$ & $0.01^{\mathrm{b}}$ & 0.00 & $<0.001$ & 0.541 & 0.003 \\
\hline $\mathrm{C} 18: 1 \mathrm{n}-9 \mathrm{c}$ & $12.40^{\mathrm{b}}$ & $12.32^{\mathrm{b}}$ & $20.01^{\mathrm{a}}$ & 0.41 & $<0.001$ & $<0.001$ & $<0.001$ \\
\hline C18:1 n-7 & $0.92^{\mathrm{b}}$ & $0.90^{\mathrm{b}}$ & $1.40^{\mathrm{a}}$ & 0.03 & $<0.001$ & 0.223 & $<0.001$ \\
\hline C20:1 n-9 & $0.15^{\mathrm{b}}$ & $0.15^{\mathrm{b}}$ & $0.29^{\mathrm{a}}$ & 0.01 & $<0.001$ & 0.048 & 0.580 \\
\hline $\mathrm{C} 22: 1 \mathrm{n}-9^{2}$ & $0^{\mathrm{b}}$ & $0^{\mathrm{b}}$ & $0.05^{\mathrm{a}}$ & 0.01 & $<0.001$ & 0.029 & 0.190 \\
\hline MUFA $^{\mathrm{a}}$ & $14.94^{\mathrm{b}}$ & $14.65^{\mathrm{b}}$ & $22.91^{\mathrm{a}}$ & 0.47 & $<0.001$ & $<0.001$ & $<0.001$ \\
\hline $\mathrm{C} 18: 2 \mathrm{n}-6 \mathrm{t}^{2}$ & 0.02 & 0.02 & 0.02 & 0.00 & 0.952 & 0.326 & $<0.001$ \\
\hline $\mathrm{C} 18: 2 \mathrm{n}-6 \mathrm{c}$ & $14.61^{\mathrm{ab}}$ & $14.41^{\mathrm{b}}$ & $14.90^{\mathrm{a}}$ & 0.08 & 0.009 & 0.185 & $<0.001$ \\
\hline$C 18: 3 n-6^{2}$ & $0.13^{\mathrm{a}}$ & $0.11^{\mathrm{a}}$ & $0.06^{\mathrm{b}}$ & 0.01 & $<0.001$ & $<0.001$ & $<0.001$ \\
\hline C18:3 n-3 & $1.40^{\mathrm{b}}$ & $1.36^{\mathrm{b}}$ & $4.03^{\mathrm{a}}$ & 0.13 & $<0.001$ & 0.862 & 0.769 \\
\hline C20:2 & 0.08 & 0.09 & 0.08 & 0.00 & 0.528 & 0.223 & 0.381 \\
\hline$C 20: 3 n-6^{2}$ & $0.03^{\mathrm{a}}$ & $0.03^{\mathrm{a}}$ & $0.02^{\mathrm{b}}$ & 0.00 & 0.043 & 0.002 & 0.664 \\
\hline C20:4 n-6 & $0.22^{\mathrm{a}}$ & $0.21^{\mathrm{a}}$ & $0.16^{\mathrm{b}}$ & 0.01 & $<0.001$ & 0.952 & $<0.001$ \\
\hline$C 20: 3 n-3$ & $0^{\mathrm{b}}$ & $0^{\mathrm{b}}$ & $0.02^{\mathrm{a}}$ & 0.001 & $<0.001$ & 0.539 & 0.409 \\
\hline C20:5 n-3 & $0.01^{\mathrm{ab}}$ & $0^{\mathrm{b}}$ & $0.02^{\mathrm{a}}$ & 0.00 & 0.012 & 0.236 & 0.735 \\
\hline C22:4 n-6 & $0.05^{\mathrm{a}}$ & $0.03^{\mathrm{a}}$ & $0.01^{\mathrm{b}}$ & 0.00 & $<0.001$ & 0.085 & 0.055 \\
\hline $\mathrm{C} 22: 5 \mathrm{n}-3^{2}$ & $0.02^{\mathrm{b}}$ & $0.02^{\mathrm{b}}$ & $0.05^{\mathrm{a}}$ & 0.01 & 0.003 & 0.001 & 0.067 \\
\hline PUFA $^{\mathrm{b}}$ & $16.56^{\mathrm{b}}$ & $16.29^{b}$ & $19.37^{\mathrm{a}}$ & 0.17 & $<0.001$ & 0.121 & $<0.001$ \\
\hline$n-6$ & 15.05 & 14.80 & 15.17 & 0.09 & 0.072 & 0.135 & $<0.001$ \\
\hline$n-3$ & $1.43^{\mathrm{b}}$ & $1.39^{\mathrm{b}}$ & $4.11^{\mathrm{a}}$ & 0.14 & $<0.001$ & 0.356 & 0.872 \\
\hline$n-6 / n-3$ & $10.58^{\mathrm{a}}$ & $10.68^{\mathrm{a}}$ & $3.70^{\mathrm{b}}$ & 0.35 & $<0.001$ & 0.029 & 0.549 \\
\hline
\end{tabular}

a,b Means within a row with different superscripts differ $(P<0.05)$.

${ }^{1}$ Group: $\mathrm{RF}=$ reproduction (Repro) diet from 0 to $25 \mathrm{~d}$ and 35 to $42 \mathrm{~d}$, followed by the fattening (Fatt) diet from 25 to $35 \mathrm{~d}$; RR = diet Repro from 0 to $42 \mathrm{~d}$; LR = lactation (Lact) diet from 0 to $25 \mathrm{~d}$, followed by diet Repro from 25 to $42 \mathrm{~d}$. Diet R (11.01 MJ DE/kg, $24.0 \mathrm{~g} \mathrm{lipids/kg,} 161 \mathrm{~g} \mathrm{starch} / \mathrm{kg}$, and $343 \mathrm{~g} / \mathrm{kg} \mathrm{NDF}$ ) was formulated to meet the nutrient needs of reproductive females. Diet F (9.73 MJ DE $/ \mathrm{kg}, 23.0 \mathrm{~g} \mathrm{lipids} / \mathrm{kg}, 70 \mathrm{~g}$ starch $/ \mathrm{kg}$, and $415 \mathrm{~g} / \mathrm{kg}$ $\mathrm{NDF}$ ) was formulated to meet the nutrient needs of fattening rabbits. Diet L (11.88 MJ DE $/ \mathrm{kg}, 49.0 \mathrm{~g}$ lipids $/ \mathrm{kg}, 161 \mathrm{~g}$ starch $/ \mathrm{kg}$, and $302 \mathrm{~g} / \mathrm{kg} \mathrm{NDF})$ was also formulated to meet the needs of reproductive females and to increase milk production.

${ }^{2}$ Fatty acids not found in diets.

with the RR group as the intermediary $(P<0.05)$. During the period of feed restriction, from 35 to $63 \mathrm{~d}$, no remaining feed was found in the feeder; therefore, feed intake corresponded to feed offered, and the feed conversion ratio $($ FCR) did not differ between groups $(0.367 \pm 0.001 ; P=0.53)$. From 63 to $70 \mathrm{~d}$, feed intake $(215 \pm 0 \mathrm{~g} / \mathrm{rabbit}$ daily; $P=0.29)$ and FCR $(0.305 \pm$ $0.001 ; P=0.66)$ were similar for all groups.
While kit BW at birth was similar (59 $\pm 1 \mathrm{~g}$; Fig. 2; $P=0.97)$, a tendency was observed as early as $\mathrm{d} 3$, where the kits in group LR were $4.7 \%$ heavier than those in the other 2 groups $(P=0.095)$. Kits in the LR group were heavier than RR kits at $\mathrm{d} 7$ and $14(P=$ 0.032 and $P<0.001$, respectively). A difference in BW was observed at $18 \mathrm{~d}$, where the kits in the LR group were $+10.2 \%$ heavier than those in the other 2 groups 
Table 6. Effect of feeding strategy on energy balance, energy intake, and BW of lactating rabbit does

\begin{tabular}{|c|c|c|c|c|c|c|c|c|c|}
\hline & \multicolumn{3}{|c|}{ Group $^{1}$} & \multirow[b]{2}{*}{ SEM } & \multicolumn{5}{|c|}{$P$-value } \\
\hline & RF & $\mathrm{RR}$ & LR & & Group & Cycle & Parity & Reproductive success $n+1$ & Group $\times$ cycle \\
\hline No. of lactations & 64 & 72 & 67 & & & & & & \\
\hline \multicolumn{10}{|l|}{ BW, g } \\
\hline Kindling & 4,200 & 4,146 & 4,197 & 18 & 0.296 & $<0.001$ & 0.177 & 0.129 & 0.983 \\
\hline AI & 4,550 & 4,551 & 4,607 & 19 & 0.229 & $<0.001$ & 0.301 & 0.632 & 0.851 \\
\hline $25 \mathrm{~d}$ & $4,616^{\mathrm{b}}$ & $4,644^{b}$ & $4,772^{\mathrm{a}}$ & 22 & 0.011 & 0.563 & 0.025 & $<0.001$ & 0.883 \\
\hline $35 \mathrm{~d}$ & 4,471 & 4,488 & 4,556 & 20 & 0.273 & 0.123 & 0.232 & 0.068 & 0.961 \\
\hline \multicolumn{10}{|c|}{ Feed intake ${ }^{2}, g \cdot d^{-1}$} \\
\hline 0 to $11 \mathrm{~d}$ & 341 & 350 & 340 & 5 & 0.317 & $<0.001$ & $<0.001$ & 0.083 & 0.913 \\
\hline 11 to $25 \mathrm{~d}$ & 432 & 434 & 424 & 5 & 0.226 & $<0.001$ & $<0.001$ & 0.035 & 0.554 \\
\hline 25 to $35 \mathrm{~d}$ & $398^{\mathrm{ab}}$ & $395^{\mathrm{b}}$ & $367^{b c}$ & 5 & 0.044 & 0.117 & $<0.001$ & 0.017 & 0.661 \\
\hline 35 to $42 \mathrm{~d}$ & $273^{\mathrm{a}}$ & $244^{\mathrm{b}}$ & $251^{\mathrm{ab}}$ & 4 & 0.006 & 0.295 & 0.115 & 0.027 & 0.522 \\
\hline \multicolumn{10}{|l|}{ DE intake, $\mathrm{MJ}$} \\
\hline 0 to $11 \mathrm{~d}$ & 41.31 & 42.46 & 44.43 & 0.58 & 0.107 & $<0.001$ & $<0.001$ & 0.072 & 0.918 \\
\hline 11 to $25 \mathrm{~d}$ & 66.54 & 66.91 & 70.55 & 0.59 & 0.060 & $<0.001$ & $<0.001$ & 0.030 & 0.576 \\
\hline 25 to $35 \mathrm{~d}$ & $38.79^{b}$ & $43.51^{\mathrm{a}}$ & $40.45^{\mathrm{ab}}$ & 0.59 & 0.003 & 0.123 & $<0.001$ & 0.019 & 0.670 \\
\hline 35 to $42 \mathrm{~d}$ & $20.71^{\mathrm{a}}$ & $18.84^{b}$ & $19.12^{\mathrm{ab}}$ & 0.38 & 0.006 & 0.295 & 0.115 & 0.027 & 0.522 \\
\hline 0 to $42 \mathrm{~d}$ & 167.35 & 171.72 & 174.56 & 1.83 & 0.441 & $<0.001$ & $<0.001$ & 0.253 & 0.610 \\
\hline \multicolumn{10}{|c|}{ Energy balance, MJ } \\
\hline 0 to $25 \mathrm{~d}$ & $-2.08^{\mathrm{a}}$ & $-2.01^{\mathrm{a}}$ & $-4.94^{b}$ & 0.67 & 0.023 & $<0.001$ & $<0.001$ & 0.056 & 0.134 \\
\hline 35 to $42 \mathrm{~d}$ & $7.14^{\mathrm{a}}$ & $3.70^{\mathrm{b}}$ & $3.63^{\mathrm{b}}$ & 0.45 & 0.003 & 0.230 & 0.077 & $<0.001$ & 0.499 \\
\hline
\end{tabular}

${ }^{\mathrm{a}-\mathrm{c}}$ Means within a row with different superscripts differ $(P<0.05)$.

${ }^{1}$ Group: reproduction-fattening $(\mathrm{RF})=$ reproduction (Repro) diet from 0 to $25 \mathrm{~d}$ and 35 to $42 \mathrm{~d}$, followed by the fattening (Fatt) diet from 25 to $35 \mathrm{~d}$; reproduction-reproduction $(\mathrm{RR})=$ diet Repro from 0 to $42 \mathrm{~d}$; lactation-reproduction $(\mathrm{LR})=$ lactation (Lact) diet from 0 to $25 \mathrm{~d}$, followed by diet Repro from 25 to $42 \mathrm{~d}$. Diet R (11.01 MJ DE/ $/ \mathrm{kg}, 24.0 \mathrm{~g}$ lipids $/ \mathrm{kg}, 161 \mathrm{~g} \mathrm{starch} / \mathrm{kg}$, and $343 \mathrm{~g} / \mathrm{kg} \mathrm{NDF}$ ) was formulated to meet the nutrient needs of reproductive females. Diet F (9.73 MJ DE $/ \mathrm{kg}, 23.0 \mathrm{~g}$ lipids $/ \mathrm{kg}, 70 \mathrm{~g}$ starch $/ \mathrm{kg}$, and $415 \mathrm{~g} / \mathrm{kg} \mathrm{NDF}$ ) was formulated to meet the nutrient needs of fattening rabbits. Diet L (11.88 MJ $\mathrm{DE} / \mathrm{kg}, 49.0 \mathrm{~g}$ lipids $/ \mathrm{kg}, 161 \mathrm{~g} \mathrm{starch} / \mathrm{kg}$, and $302 \mathrm{~g} / \mathrm{kg} \mathrm{NDF}$ ) was also formulated to meet the needs of reproductive females and to increase milk production.

${ }^{2}$ The feed intake presented is strictly that of the doe, as rabbit kits were inhibited from eating out of the doe feeder.

$(P<0.001)$. However, a group $\times$ cycle interaction was observed concerning the BW of kits at 18 and $25 \mathrm{~d}$ $(P<0.05)$. At $18 \mathrm{~d}$, animals in group RR were heavier $(P<0.05)$ in $\mathrm{C} 2$ and lighter in $\mathrm{C} 1$ and $\mathrm{C} 3$ compared to those in group RF, with a maximum difference of $9 \mathrm{~g}$ (3\%) between the 2 groups in C2. At $25 \mathrm{~d}$, animals in group RR were heavier $(P<0.05)$ than those in group $\mathrm{RF}$ in $\mathrm{C} 2$ and $\mathrm{C} 3$ but lighter in $\mathrm{C} 1$. At weaning, the BW of young rabbits was similar between the groups $(P=0.37)$. This may be explained by the greater feed intake between $\mathrm{d} 25$ and 35 in the RF group compared to the LR group ( $+8 \% ; P<0.05)$, with group RR as the intermediate. At d 70, BW was similar between groups $(2,322 \pm 4 \mathrm{~g} ; P=0.17)$.

\section{Mortality of Young Rabbits}

Kit mortality from equalization (d 3 ) to weaning (d 35) was similar between groups $(7.8 \pm 0.01 \%$ on average for each group; $P=0.75$; data not shown). Between weaning and $\mathrm{d} 70$, the mortality in group RF was lower than that in the other 2 groups $(1.7 \pm 0.1 \%$ compared to $4.8 \pm 0.1 \%$ and $5.8 \pm 0.1 \%$ for the groups RR and LR, respectively; $P=0.001)$. Overall mortality between $\mathrm{d} 3$ and 70 was similar between the RR and LR groups $(12.6 \pm 0.01 \%$ and $13.9 \pm 0.01 \%$, respectively) but lower in the RF group $(9.2 \pm 0.01 \% ; P=0.046)$.

\section{DISCUSSION}

The energy requirements for overlapping lactation and gestation of rabbit does are very high, and this requirement is not fully covered by voluntary feed intake, especially in primiparous does. Numerous propositions to improve the performances and longevity of does have been suggested, including changes in reproductive rhythm (Castellini et al., 2010; AlfonsoCarrillo et al., 2014), genetic selection (Garreau et al., 2004; Ragab and Baselga, 2011), and feeding strategies (Pascual et al., 2003; Menchetti et al., 2015).

\section{Feed Intake and Body Weight of Females}

The regulation of appetite in reproductive female rabbits is primarily controlled by a chemostatic mechanism, which regulates the voluntary feed intake as a function of the energy content of the feed to ensure an adequate energy supply (Pascual, 2004). Thus, we expect feed intake to be greater in the RF group between 25 and $35 \mathrm{~d}$. Surprisingly, no differences were 
Table 7. Effect of the feeding strategy on feed intake, ADG, and feed conversion ratio of young rabbits

\begin{tabular}{|c|c|c|c|c|c|c|c|c|c|}
\hline & \multicolumn{3}{|c|}{ Group $^{1}$} & \multirow[b]{2}{*}{ SEM } & \multicolumn{5}{|c|}{$P$-value } \\
\hline & $\mathrm{RF}$ & $\mathrm{RR}$ & LR & & Group & Cycle & Parity & Reproductive success $n-1$ & Group $\times$ cycle \\
\hline No. of animals & 629 & 663 & 654 & & & & & & \\
\hline \multicolumn{10}{|c|}{ Feed intake, $g \cdot$ rabbit $^{-1} \cdot \mathrm{d}^{-1}$} \\
\hline 18 to $25 \mathrm{~d}$ & $9^{a}$ & $10^{\mathrm{a}}$ & $7^{b}$ & 0.1 & $<0.001$ & $<0.001$ & 0.438 & 0.554 & 0.518 \\
\hline 25 to $35 \mathrm{~d}$ & $50^{\mathrm{a}}$ & $48^{\mathrm{ab}}$ & $46^{\mathrm{b}}$ & 0.1 & 0.013 & $<0.001$ & 0.381 & 0.039 & 0.911 \\
\hline 35 to $63 \mathrm{~d}$ & 103 & 103 & 103 & $\mathrm{NC}^{2}$ & $\mathrm{NC}$ & $\mathrm{NC}$ & $\mathrm{NC}$ & $\mathrm{NC}$ & $\mathrm{NC}$ \\
\hline 63 to $70 \mathrm{~d}$ & 213 & 214 & 219 & 0.8 & 0.439 & $<0.001$ & 0.031 & $<0.001$ & 0.674 \\
\hline 35 to $70 \mathrm{~d}$ & 125 & 125 & 125 & 0.1 & 0.897 & $<0.001$ & $<0.001$ & 0.763 & 0.130 \\
\hline \multicolumn{10}{|l|}{$A D G, g \cdot d^{-1}$} \\
\hline Birth to $18 \mathrm{~d}$ & $12.7^{\mathrm{b}}$ & $12.8^{\mathrm{b}}$ & $14.6^{\mathrm{a}}$ & 0.2 & $<0.001$ & $<0.001$ & $<0.001$ & $<0.001$ & 0.148 \\
\hline 18 to $25 \mathrm{~d}$ & 15.8 & 15.6 & 16.1 & 0.1 & 0.926 & 0.014 & 0.106 & $<0.001$ & 0.055 \\
\hline 25 to $35 \mathrm{~d}$ & 39.6 & 39.8 & 38.6 & 0.1 & 0.144 & $<0.001$ & 0.017 & $<0.001$ & 0.085 \\
\hline 35 to $63 \mathrm{~d}$ & 37.9 & 37.9 & 38.3 & 0.1 & 0.641 & $<0.001$ & 0.271 & 0.647 & 0.957 \\
\hline 63 to $70 \mathrm{~d}$ & 65.1 & 66.1 & 66.3 & 0.3 & 0.574 & $<0.001$ & 0.187 & 0.508 & 0.724 \\
\hline 35 to $70 \mathrm{~d}$ & 43.4 & 43.6 & 43.9 & 0.1 & 0.358 & 0.075 & 0.006 & 0.147 & 0.893 \\
\hline \multicolumn{10}{|c|}{ Feed conversion ratio } \\
\hline 35 to $63 \mathrm{~d}$ & 0.366 & 0.366 & 0.369 & 0.001 & 0.534 & 0.029 & $<0.001$ & 0.761 & 0.994 \\
\hline 63 to $70 \mathrm{~d}$ & 0.304 & 0.308 & 0.303 & 0.001 & 0.663 & 0.041 & $<0.001$ & 0.837 & 0.826 \\
\hline 35 to $70 \mathrm{~d}$ & 0.346 & 0.349 & 0.350 & 0.001 & 0.359 & 0.046 & 0.003 & 0.067 & 0.802 \\
\hline
\end{tabular}

a,b Means within a row with different superscripts differ $(P<0.05)$.

${ }^{1}$ Group: reproduction-fattening (RF) = reproduction (Repro) diet from 0 to $25 \mathrm{~d}$ and 35 to $42 \mathrm{~d}$, followed by the fattening (Fatt) diet from 25 to $35 \mathrm{~d}$; reproduction-reproduction $(\mathrm{RR})=\operatorname{diet}$ Repro from 0 to $42 \mathrm{~d}$; lactation-reproduction $(\mathrm{LR})=$ lactation (Lact) diet from 0 to $25 \mathrm{~d}$, followed by diet Repro from 25 to 42 d. Diet Repro (11.01 MJ DE/kg, $24.0 \mathrm{~g}$ lipids $/ \mathrm{kg}, 161 \mathrm{~g}$ starch $/ \mathrm{kg}$, and $343 \mathrm{~g} / \mathrm{kg} \mathrm{NDF}$ ) was formulated to meet the nutrient needs of reproductive females. Diet Fatt (9.73 MJ DE $/ \mathrm{kg}, 23.0 \mathrm{~g}$ lipids $/ \mathrm{kg}, 70 \mathrm{~g}$ starch $/ \mathrm{kg}$, and $415 \mathrm{~g} / \mathrm{kg} \mathrm{NDF}$ ) was formulated to meet the nutrient needs of fattening rabbits. Diet Lact (11.88 MJ $\mathrm{DE} / \mathrm{kg}, 49.0 \mathrm{~g}$ lipids $/ \mathrm{kg}, 161 \mathrm{~g} \mathrm{starch} / \mathrm{kg}$, and $302 \mathrm{~g} / \mathrm{kg} \mathrm{NDF}$ ) was also formulated to meet the needs of reproductive females and to increase milk production.

${ }^{2} \mathrm{NC}=$ noncalculable, as the variance of the feed intake for restricted groups is null.

observed between feeding strategies during this period, while we observed a greater feed intake in this group in the subsequent period. We hypothesize that females reached their maximum ingestion capacity when they were fed the F diet and compensate their intake in the subsequent period. Generally, fat inclusion in the diet leads to a decrease in feed intake: $-2.6 \%$ for each $1 \%$ increase in ether extract (Castellini and Batteglini, 1991; Cervera et al., 1993; Xiccato et al., 1995), but effects are not always significant (Fernández-Carmona et al., 1996; Pascual et al., 2000a) depending on studies. On the other hand, all of the studies reported that fat inclusion in the diet permits an increase in DE intake.

\section{Reproductive Performances}

While this study shows that the feeding strategy had no effect on the fertility rate of females, previous studies concerning the effects of feed composition before AI on fertility have led to controversial results. In breeding systems with mating 10 to $14 \mathrm{~d}$ postpartum, energy source did not have an effect on the fertility rate of rabbit does (Castellini and Batteglini, 1991). In a more recent study, Fortun-Lamothe et al. (2005) observed that the fertility rate of rabbit does was maintained at around $82 \%$ when the diet was rich in fat compared to a decrease in the fertility of rabbits receiving a diet rich in fiber and poor in fat. Despite the use of PMSG and GnRH, the fertility rate in this study was low, which may be due to the high frequency of manipulation of does for collection of data. However, AI $11 \mathrm{~d}$ postpartum was reported to have a negative effect on body condition, which led to a low fertility rate (50.9\%; Cardinali et al., 2008). The introduction of light stimulation may help improve the fertility rate in future studies (Theau-Clément, 2007).

Numerous studies have observed that increasing the dietary fat or starch content has no effect on litter size at birth (Pascual et al., 2003). In this study, the number of live born tended to be greater when does received diets enriched in fat. The litter weight at birth was greater in does fed fat-enriched diets, although this may be explained by the values for litter size. In this study, the diet of the doe did not affect kit viability from birth until weaning. Contrary to a number of studies that observed an increase in litter survival with the addition of dietary fat in the doe diet (FernándezCarmona et al., 2000; Pascual et al., 2000b; Pascual et al., 2002), no differences were observed in this study.

\section{Milk Production and Composition}

As in the literature, the milk production of the females in this study was greater with the addition of fat in the diet (Maertens et al., 2006). Due to the increase in 


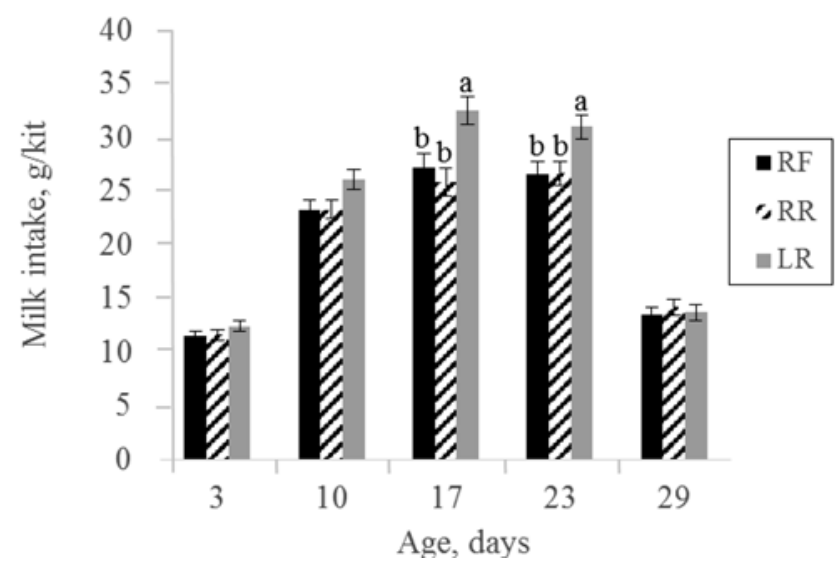

Figure 1. Effect of feeding strategy on milk intake in kits $(n=15$ litters per treatment). Group: reproduction-fattening $(\mathrm{RF})=$ reproduction (Repro) diet from 0 to $25 \mathrm{~d}$ and 35 to $42 \mathrm{~d}$, followed by the fattening (Fatt) diet from 25 to $35 \mathrm{~d}$; reproduction-reproduction $(\mathrm{RR})=$ diet Repro from 0 to $42 \mathrm{~d}$; lactation-reproduction $(\mathrm{LR})=$ lactation (Lact) diet from 0 to 25 d, followed by diet Repro from 25 to $42 \mathrm{~d}$. Diet R (11.01 MJ DE/kg, 24.0 $\mathrm{g}$ lipids $/ \mathrm{kg}, 161 \mathrm{~g} \mathrm{starch} / \mathrm{kg}$, and $343 \mathrm{~g} / \mathrm{kg} \mathrm{NDF}$ ) was formulated to meet the nutrient needs of reproductive females. Diet Fatt $(9.73 \mathrm{MJ} \mathrm{DE} / \mathrm{kg}, 23.0$ $\mathrm{g}$ lipids $/ \mathrm{kg}, 70 \mathrm{~g}$ starch $/ \mathrm{kg}$, and $415 \mathrm{~g} / \mathrm{kg} \mathrm{NDF}$ ) was formulated to meet the nutrient needs of fattening rabbits. Diet Lact $(11.88 \mathrm{MJ} \mathrm{DE} / \mathrm{kg}, 49.0 \mathrm{~g}$ lipids $/ \mathrm{kg}, 161 \mathrm{~g} \mathrm{starch} / \mathrm{kg}$, and $302 \mathrm{~g} / \mathrm{kg} \mathrm{NDF}$ ) was also formulated to meet the needs of reproductive females and to increase milk production. Bars within a row with different lowercase letters $(\mathrm{a}, \mathrm{b}) \operatorname{differ}(P<0.05)$.

milk yield, the milk intake of kits was greater, which had a positive effect on BW. In this study, milk fat content at $16 \mathrm{~d}$ postpartum was similar between groups, with an average of $9.5 \%$. This is lower than the numbers previously cited in the literature (12\% during the third week of lactation; Maertens et al., 2006). The effect of the fat content of the diet on milk lipid content is controversial. Pascual et al. (1999) observed that a high content of fat in the diet increased the lipid content of milk. On the contrary, Xiccato et al. (1995) observed no difference in milk composition at $22 \mathrm{~d}$ after parturition with the inclusion of animal fat in the diet. Maertens et al. (2006) explained discrepancies found in the literature by the type of FA added to the diet, that is, when does were fed diets with similar crude fat levels, an increase of lipid content in milk was observed in does fed a diet 3 times more rich in n-3 FA. In our study, does were fed a diet that was around 2 times richer in n-3 FA, and no differences in total fat content was observed.

The percentages of SFA, MUFA, and PUFA were correlated to the content observed in the diets, which is similar to the results obtained by Castellini et al. (2004). In the present study, $\mathrm{C}: 8$ to $\mathrm{C}: 12$ represented around $49 \%$ of the total FA for all groups, which is similar to the FA profile previously observed (Kowalska and Bielanski, 2005; Maertens et al., 2006). This is an intermediate value compared to the $35 \%$ for the basal diet and $70 \%$ for the basal diet enriched with $4 \%$ rapeseed oil reported by Kowalska and Bielanski (2005). In a more recent study, Volek et al. (2014) observed a range of 48

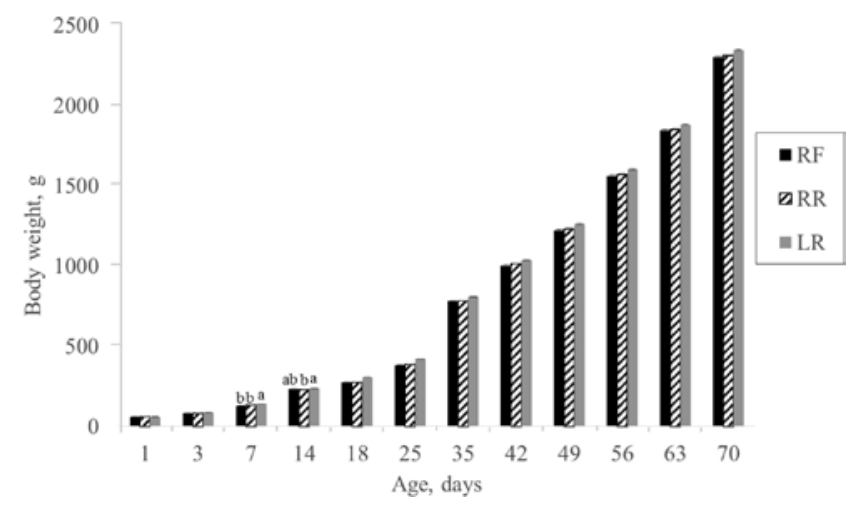

Figure 2. Effect of feeding strategy on BW of rabbit kits $(n=748$, 770 , and 804 for the reproduction-fattening [RF], reproduction-reproduction [RR], and lactation-reproduction [LR] groups, respectively, at $0 \mathrm{~d}$ ). Group: $\mathrm{RF}=$ reproduction (Repro) diet from 0 to 25 and 35 to $42 \mathrm{~d}$, followed by the fattening (Fatt) diet from 25 to $35 \mathrm{~d}$; RR = diet Repro from 0 to $42 \mathrm{~d}$; $\mathrm{LR}=$ lactation (Lact) diet from 0 to $25 \mathrm{~d}$, followed by diet Repro from 25 to $42 \mathrm{~d}$. Diet Repro (11.01 MJ DE/kg, $24.0 \mathrm{~g}$ lipids $/ \mathrm{kg}, 161 \mathrm{~g}$ starch $/ \mathrm{kg}$, and $343 \mathrm{~g} / \mathrm{kg} \mathrm{NDF}$ ) was formulated to meet the nutrient needs of reproductive females. Diet Fatt $(9.73 \mathrm{MJ} \mathrm{DE} / \mathrm{kg}, 23.0 \mathrm{~g}$ lipids $/ \mathrm{kg}, 70 \mathrm{~g}$ $\mathrm{starch} / \mathrm{kg}$, and $415 \mathrm{~g} / \mathrm{kg} \mathrm{NDF}$ ) was formulated to meet the nutrient needs of fattening rabbits. Diet Lact (11.88 MJ DE $/ \mathrm{kg}, 49.0 \mathrm{~g}$ lipids $/ \mathrm{kg}, 161 \mathrm{~g}$ starch $/ \mathrm{kg}$, and $302 \mathrm{~g} / \mathrm{kg} \mathrm{NDF}$ ) was also formulated to meet the needs of reproductive females and to increase milk production. Bars within a row with different superscripts $(\mathrm{a}, \mathrm{b})$ differ $(P<0.05)$.

to $53 \%$ of short-chain FA for diets containing soybean and sunflower meal or white lupin seeds, respectively. The quantities of FA reported by Volek et al. (2014), notably C18:1 and C18:2, ranged from 12 to $18 \%$ and 11 to $12 \%$, respectively. Our study showed similar results for the former when all forms were taken into consideration and a greater percentage for the latter, which may be due to FA levels in the diets. A total of 6 FA were observed in the milk produced by the females, which were not present in the experimental diets. Their presence is due to FA synthesis by the mammary gland and the uptake of FA from the blood (Carey and Dils, 1972).

\section{Energy Balance}

The voluntary feed intake of reproducing does is insufficient to cover the competing demands of gestation and lactation, leading to the mobilization of body reserves, which in turn has negative effects on performance (Fortun-Lamothe, 2006; Castellini et al., 2010). Similar to previous studies, a negative energy balance was observed during lactation; however, the values calculated in this study were more moderate (Parigi-Bini et al., 1990). During the last week before kindling, the voluntary feed intake of the does was sufficient to cover the needs of the growing fetuses. Previous studies found that energy requirements during late pregnancy become relevant due to the development of the gravid uterus and fetal growth (Castellini et al., 2010), yet contrary to our results, the energy requirements were not covered 
due to a sharp decrease in energy intake observed after weaning (Xiccato and Trocino, 2010). Body weight was not affected by the difference in energy balance, which supports the observation that BW is not the most adapted indicator for determining the energy resources of reproductive rabbit does. In previous studies, important changes to the proportion of fat, protein, and ash in rabbit does throughout the reproductive cycle have been observed (Fortun-Lamothe et al., 2002).

\section{Kit Performances}

The solid feed intake was lower in rabbits whose mothers were fed a fat-enriched diet, which may be explained by the regulatory effect of milk availability on solid feed intake as previously observed in numerous studies (Gidenne and Fortun-Lamothe, 2002). Studies have demonstrated that litters of females offered fat-rich diets consumed up to $21 \%$ less feed than litters of females offered control diets (Pascual et al., 2003). Inclusion of fat in the doe's diet has been linked to an increase of $12 \%$ of milk production (Fortun-Lamothe, 1997).

While the BW of kits at birth were similar in all groups, kits were significantly heavier at $18 \mathrm{~d}$ of age when their mother received the fat-enriched diet. As rabbit kits did not have access to solid feed before $\mathrm{d} 18$, this difference is strictly due to milk intake. An increase in kit weight gain from +3 to $+16 \mathrm{~g} / \mathrm{d}$ with the incorporation of fat in the doe's diet has been observed in a large number of previous studies (Pascual et al., 2003). Similar to previous observations, at the time of weaning, litter weight was similar in all groups because lower milk availability was compensated by a greater ingestion of solid feed (Xiccato et al., 1995; Gidenne and Fortun-Lamothe, 2002) leading to compensatory growth.

In this study, kit mortality from equalization to weaning was similar between groups. Contrary to this, Fraga et al. (1989) showed that kit survival before weaning was improved when doe diets were enriched in fat. Kit mortality between weaning and d 70 was found to be lower in animals whose mothers underwent a feed change $1 \mathrm{wk}$ before weaning, from an energy-rich feed to a feed less dense in energy and with a greater fiber content. In the present study, the lower milk intake led to a greater solid feed intake before weaning, which may allow for a faster maturation of the cecal microbiota (Read et al., unpublished data).

\section{Conclusion}

This experiment explored 2 feeding strategies for reproductive females based on a separate feeding system between mother and suckling rabbits. The results showed weak effects concerning measurements of females, ex- cept a stimulation of milk production. A lower mortality in fattening rabbits when their mother was offered a low-energy diet at the end of lactation was also observed. Therefore, strategies based on the stimulation of milk production during the beginning of lactation offer few benefits for females, and interest in kit growth in early life has been shown to be detrimental on their early solid feed intake and thus on their health after weaning. The use of a single diet, rich in energy, for females throughout their reproductive life may be a simpler feeding strategy, but its interest compared to actual practice remains to be demonstrated over a longer period, mainly concerning consequences on rabbit health after weaning.

\section{LITERATURE CITED}

AFNOR. 1997. Norme Française homologuée, Aliments des animaux. Détermination séquentielle des constituants pariétaux. Méthode par traitement aux détergents neutre et acide et à l'acide sulfurique. AFNOR publ., Paris, France.

Alfonso-Carrillo, C., E. Martín, C. De Blas, M. Á. Ibáñez, P. GarcíaRebollar, and A. I. García-Ruiz. 2014. Effect of cage type on the behaviour patterns of rabbit does at different physiological stages. World Rabbit Sci. 22:59-69.

Cardinali, R., A. Dal Bosco, A. Bonanno, A. Di Grigoli, P. Rebollar, P. Lorenzo, and C. Castellini. 2008. Connection between body condition score, chemical characteristics of body and reproductive traits of rabbit does. Livest. Sci. 116:209-215.

Carey, E., and R. Dils. 1972. The pattern of fatty acid synthesis in lactating rabbit mammary gland studied in vivo. Biochem. J. 126:1005-1007.

Castellini, C., and M. Batteglini. 1991. Influenza della concentrazione energética della razione e del ritmo riproduttivo sille performance delle coniglie. In: Att. IX Congresso Nazionale ASPA. p. 477-488.

Castellini, C., A. Dal Bosco, M. Arias-Álvarez, P. L. Lorenzo, R. Cardinali, and P. G. Rebollar. 2010. The main factors affecting the reproductive performance of rabbit does: A review. Anim. Reprod. Sci. 122:174-182.

Castellini, C., A. Dal Bosco, R. Cardinali, C. Mugnai, and E. Sciascia. 2004. Effect of dietary N-3 fatty acids on the composition of doe's milk and tissues of suckling rabbits. In: Proc. 8th World Rabbit Congr., Puebla, Mexico. p. 771-777.

Cervera, C., J. Fernandez-Carmona, P. Viudes, and E. Blas. 1993. Effect of remating interval and diet on the performance of female rabbits and their litters. Anim. Prod. 56:399-405.

De Blas, C., and G. Mateos. 2010. Feed formulation. In: C. De Blas and J. Wiseman, editors, Nutrition of the rabbit. CABI, Wallingford, UK. p. 222-232.

EGRAN. 2001. Technical note: Attempts to harmonise chemical analyses of feeds and faeces, for rabbit feed evaluation. World Rabbit Sci. 9:57-64.

European Union. 2010. Protection of animals used for scientific purpose. Off. J. Eur. Union L276/33 - L276/79, 303 :1 - 30.

Fernández-Carmona, J., C. Cervera, and E. Blas. 1996. High fat diets for rabbit breeding does housed at $30^{\circ} \mathrm{C}$. In: Proc. 6th World Rabbit Congr., Toulouse, France. p. 167-169.

Fernández-Carmona, J., S. Santiago, I. Alqedra, C. Cervera, and J. Pascual. 2000. Effect of luzerne-based diets on the reproductive performance of rabbit does at high environmental temperatures. In: Proc. 7th World Rabbit Congr., Valencia, Spain. p. 203-208.

Folch, J., M. Lees, and G. H. Sloane Stanley. 1957. A simple method for the isolation and purification of total lipides from animal tissues. J. Biol. Chem. 226:497-509. 
Fortun-Lamothe, L. 1997. Effects of dietary fat in reproductive performance of rabbit does. World Rabbit Sci. 5:33-38.

Fortun-Lamothe, L. 2006. Energy balance and reproductive performance in rabbit does. Anim. Reprod. Sci. 93:1-15.

Fortun-Lamothe, L., T. Gidenne, A. Lapanouse, and J. De Dapper. 2000. Note: An original system to separately control litter and female feed intake without modification of the mother-young relations. World Rabbit Sci. 8:177-180.

Fortun-Lamothe, L., L. Lacanal, P. Boisot, N. Jehl, P. Arveux, J. Hurtaud, and G. Perrin. 2005. Effects of level and origin of dietary energy on reproduction performance of the does and health status of the young. In: Proc. 11èmes J. Rech. Cunicoles, Paris. p. 129-132.

Fortun-Lamothe, L., B. Lamboley-Gauzere, and C. Bannelier. 2002. Prediction of body composition in rabbit females using total body electrical conductivity (TOBEC). Livest. Prod. Sci. 78:133-142.

Fortun-Lamothe, L., A. Prunier, G. Bolet, and F. Lebas. 1999. Physiological mechanisms involved in the effects of concurrent pregnancy and lactation on foetal growth and mortality in the rabbit. Livest. Prod. Sci. 60:229-241.

Fortun-Lamothe, L., and F. Sabater. 2003. Estimation de la production laitière des lapines à partir de la croissance des lapereaux. In: Proc. 10ème J. Rech. Cunicoles, Le Mans, France. p. 19-20.

Fraga, M., M. Lorente, R. Carabano, and J. De Blas. 1989. Effect of diet and of remating interval on milk production and milk composition of the doe rabbit. Anim. Prod. 48:459-466.

Garreau, H., M. Piles, C. Larzul, M. Baselga, and H. D. Rochambeau. 2004. Selection of maternal lines: Last results and prospects. In: Proc. 8th World Rabbit Congr., Pueblo, Mexico. p. 14-18.

Gidenne, T. 2003. Fibres in rabbit feeding for digestive troubles prevention: Respective role of low-digested and digestible fibre. Livest. Prod. Sci. 81:105-117.

Gidenne, T. 2015. Dietary fibres in the nutrition of the growing rabbit and recommendations to preserve digestive health: A review. Animal 9:227-242.

Gidenne, T., and L. Fortun-Lamothe. 2002. Feeding strategy for young rabbits around-weaning: A review of digestive capacity and nutritional needs. Anim. Sci. 75:169-184.

Kowalska, D., and P. Bielanski. 2005. Effect of supplemental dietary fat for rabbits on milk composition and rearing performance of young rabbits. In: Proc. 8th World Rabbit Congr., Pueblo, Mexico. p. 869-873.

Lebas, F. 1968. Mesure quantitative de la production laitière chez la lapine. Ann. Zootech. 17:169-182.

Lebas, F. 1970. Description d'une machine à traire les lapines. Ann. Zootech. 19:223-228.

Maertens, L., F. Lebas, and Z. Szendro. 2006. Rabbit milk: A review of quantity, quality and non-dietary affecting factors. World Rabbit Sci. 14:205-230.

Maertens, L., J. Perez, M. Villamide, C. Cervera, T. Gidenne, and G. Xiccato. 2002. Nutritive value of raw materials for rabbits: Egran tables 2002. World Rabbit Sci. 10:157-166.

Menchetti, L., G. Brecchia, R. Cardinali, A. Polisca, and C. Boiti. 2015. Food restriction during pregnancy: Effects on body condition and productive performance of primiparous rabbit does. World Rabbit Sci. 23:1-8.

Morrison, W. R., and L. M. Smith. 1964. Preparation of fatty acid methyl esters and dimethylacetals from lipids with boron fluoride-methanol. J. Lipid Res. 5:600-608.
Parigi-Bini, R., and G. Xiccato. 1998. Energy metabolism and requirements. In: C. De Blas and J. Wiseman, editors, The nutrition of the rabbit. CABI, Wallingford, UK. p. 103-131.

Parigi-Bini, R., G. Xiccato, and M. Cinetto. 1990. Répartition de l'énergie alimentaire chez la lapine non gestante pendant la première lactation. In: Proc. 5èmes J. Rech. Cunicole, Paris, France. p. 47-51.

Pascual, J. 2004. Animal feeding factors affecting voluntary feed intake of reproductive rabbit does. In: Proc. 55th Annual Meeting EAAP, Bled, Slovania. p. 176-180.

Pascual, J., C. Cervera, E. Blas, and J. Fernández-Carmona. 1999. Effect of high fat diets on the performance, milk yield and milk composition of multiparous rabbit does. Anim. Sci. 68:151-162.

Pascual, J., C. Cervera, E. Blas, and J. Fernández-Carmona. 2003. High-energy diets for reproductive rabbit does: Effect of energy source. Nutr. Abstr. Rev. 73:27R-39R.

Pascual, J., C. Cervera, and J. Fernández-Carmona. 2000a. The effect of dietary fat on the performance and body composition of rabbits in their second lactation. Anim. Feed Sci. Technol. 86:191-203.

Pascual, J., M. Fonfría, I. Alqedra, C. Cervera, and J. FernándezCarmona. 2000b. Use of luzerne-based diets on reproductive rabbit doe. In: 7th World Rabbit Congr., Valencia, Spain. p. 379-384.

Pascual, J., W. Motta, C. Cervera, F. Quevedo, E. Blas, and J. Fernández-Carmona. 2002. Effect of dietary energy source on the performance and perirenal fat thickness evolution of primiparous rabbit does. Anim. Sci. 75:267-279.

Perez, J., F. Lebas, T. Gidenne, L. Maertens, G. Xiccato, R. ParigiBini, and A. Dalle Zotte. 1995. European reference method for in vivo determination of diet digestibility in rabbits. World Rabbit Sci. 3:41-43.

Ponter, A., D. Sauvant, J.-M. Perez, and G. Tran. 2004. Tables of composition and nutritional value of feed materials: Pigs, poultry, cattle, sheep, goats, rabbits, horses and fish. Wageningen Academic Publishers, Wageningen, The Netherlands.

Poujardieu, B., and M. Theau-Clément. 1995. Productivité de la lapine et état physiologique. Ann. Zootech. 44:29-39.

Ragab, M., and M. Baselga. 2011. A comparison of reproductive traits of four maternal lines of rabbits selected for litter size at weaning and founded on different criteria. Livest. Sci. 136:201-206.

Savietto, D., S. Marono, I. Martínez, E. Martínez-Paredes, L. Ródenas, C. Cervera, and J. Pascual. 2016. Patterns of body condition use and its impact on fertility. World Rabbit Sci. 24:39-45.

Theau-Clément, M. 2007. Preparation of the rabbit doe to insemination: A review. World Rabbit Sci. 15:61-80.

Van Soest, P., J. Robertson, and B. Lewis. 1991. Symposium: Carbohydrate methodology, metabolism, and nutritional implications in dairy cattle. J. Dairy Sci. 74:3583-3597.

Volek, Z., M. Marounek, L. Volková, and E. Kudrnová. 2014. Effect of diets containing whole white lupin seeds on rabbit doe milk yield and milk fatty acid composition as well as the growth and health of their litters. J. Anim. Sci. 92:2041-2049.

Xiccato, G., R. Parigi-Bini, A. Dalle Zotte, A. Carazzolo, and M. Cossu. 1995. Effect of dietary energy level, addition of fat and physiological state on performance and energy balance of lactating and pregnant rabbit does. Anim. Sci. 61:387-398.

Xiccato, G., and A. Trocino. 2010. Energy and protein metabolism and requirements. In: C. De Blas and J. Wiseman, editors, Nutrition of the rabbit. CABI, Wallingford, UK. p. 83-118. 